Journal of Economic, Business and Accounting (COSTING)

Volume 1 Nomor 2, Juni 2018

e-ISSN : 2597-5234

https://doi.org/10.31539/costing.v1i2.213

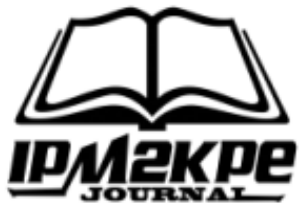

\title{
PENGARUH REKRUTMEN DAN PENEMPATAN KERJA TERHADAP PRODUKTIVITAS KERJA KARYAWAN PADA PT. SINDANG BROTHERS KOTA LUBUKLINGGAU
}

\section{THE EFFECT OF RECRUITMENT AND WORK PLACEMENT ON EMPLOYEE PRODUCTIVITY ON EMPLOYEES PT. SINDANG BROTHERS CITY LUBUKLINGGAU}

\author{
Wisdalia Maya Sari \\ Sekolah Tinggi Manajemen dan Ilmu Komputer Musi Rawas Lubuklinggau \\ wisdaliams6@gmail.com
}

\begin{abstract}
Success or failure of the organization in achieving the goals set previously depends on the ability of human resources (employees) in carrying out the task or work given. This study aims to determine the effect of recruitment and job placement on employee productivity at PT.Sindang Brothers Lubuklinggau City. The method of data processing was saturated sampling approach that is the sampling method that the entire population amount is used as research sample which amounted to 47 employees. Data analysis conducted by validity and reliability test, normality test, classical assumption test, simple linear regression test, determination test, $F$ test and $T$ test. Based on the result of research, it is concluded that Recruitment and Work Placement partially have significant effect on Work Productivity at PT. Sindang Brothers Town of Lubuklinggau. The effect of recruitment on work productivity is $83.6 \%$ and the remaining 16.4 is influenced by other variable variables outside the research. While the effect of placement on work productivity is $87.6 \%$ and the rest 12.4 is influenced by other variable variables.
\end{abstract}

Keywords: Recruitment, Job Placement, and Work Productivity

\begin{abstract}
ABSTRAK
Berhasil atau tidaknya organisasi dalam mencapai tujuan yang ditetapkan sebelumnya sangat tergantung pada kemampuan sumber daya manusianya (karyawan) dalam menjalankan tugas atau pekerjaan yang diberikan kepadanya. Penelitian ini bertujuan untuk mengetahui pengaruh rekrutmen dan penempatan kerja terhadap produktivitas kerja karyawan pada PT.Sindang Brothers Kota Lubuklinggau. Metode pengolahan data dilakukan dengan pendekatan sampling jenuh yaitu metode pengambilan sampel yang seluruh jumlah populasinya dijadikan sampel penelitian yang berjumlah 47 karyawan. Analisis data yang dilakukan secara uji validitas dan reliabilitas, uju normalitas, uji asumsi klasik, uji regresi linier sederhana, uji determinasi, uji F serta uji T. Berdasarkan hasil penelitian, disimpulkan bahwa Rekrutmen dan Penempatan Kerja secara parsial berpengaruh secara signifikan terhadap Produktivitas Kerja pada PT. Sindang Brothers Kota Lubuklinggau. Pengaruh rekrutmen terhadap produktivitas kerja adalah sebesar $83,6 \%$ dan sisanya 16,4 dipengaruhi oleh variabel variabel lain diluar penelitian. Sedangkan pengaruh penempatan terhadap produktivitas kerja adalah sebesar $87,6 \%$ dan sisanya 12,4 dipengaruhi oleh variabel variabel lain.
\end{abstract}

Kata Kunci: Rekrutmen, Penempatan Kerja, dan Produktivitas kerja 


\section{PENDAHULUAN}

Berhasil atau tidaknya organisasi dalam mencapai tujuan yang ditetapkan sebelumnya sangat tergantung pada kemampuan sumber daya manusianya (karyawan) dalam menjalankan tugas atau pekerjaan yang diberikan kepadanya. Supaya sumber daya manusia tersebut dapat meningkatkan kelancaran jalannya suatu organisasi, maka organisasi tersebut harus dapat memecahkan berbagai macam permasalahan yang menyangkut ketenagakerjaan pada organisasinya. Oleh karena itu setiap organisasi harus memberikan perhatian kepada hal-hal yang berhubungan dengan fungsi sumber daya manusia baik dalam merencanakan, mengorganisasi, menyusun, mengarahkan dan mengawasi faktorfaktor produksi terutama tenaga kerja. Agar dapat memperolah tenaga kerja yang benar-benar dapat merealisasikan tujuan organisasi, maka pelaksanaan perekrutan, seleksi dan penempatan tenaga kerja harus diperhatikan dalam rangka mencapai daya guna dan hasil guna tenaga kerja yang sebesarbesarnya.

Untuk dapat memutuskan perekrutan, seleksi dan penempatan tenaga kerja, maka organisasi harus memiliki sesuatu sistem atau pedoman yang tepat. Perekrutan tenaga kerja dimaksudkan untuk pengadaan dan penarikan tenaga kerja guna mengisi posisi dan formasi yang belum terisi maupun bagian atau tugas baru yang diciptakan dalam organisasi. Agar dapat memperoleh tenaga kerja yang benarbenar cakap dan sesuai dengan harapan organisasi maka sebelum perekrutan tenaga kerja dilakukan hendaknya berbagai faktor yang berkaitan dengan perekrutan harus mendapat perhatian organisasi agar perekrutan tenaga kerja tersebut dapat direncanakan dan dilaksanakan dengan baik.

$$
\text { Seleksi tenaga kerja }
$$

dimaksudkan untuk memilih tenaga kerja yang memenuhi persyaratan, baik kuantitas dan kualitasnya. Oleh karenanya merupakan suatu keharusan untuk mengadakan pemilihan dari tenaga-tenaga kerja yang bersedia bekerja dalam organisasi agar mendapatkan orang-orang yang mempunyai kualifikasi sesuai dengan kebutuhan. Organisasi harus menyadari bahwa tidak ada artinya jika menempatkan tenaga kerja yang tidak cakap atau tidak mempunyai kualifikasi yang sesuai dengan suatu jabatan yang akan diberikan.

Demikian juga halnya dalam pengambilan keputusan untuk penempatan tenaga kerja harus mendapat perhatian agar memperoleh tenaga kerja yang memenuhi kualifikasi dan harapan organisasi. Penempatan tenaga kerja dimaksudkan untuk menempatkan tenaga kerja sebagai unsur pelaksana pekerjaan pada posisi yang sesuai dengan kemampuan, kecakapan, dan keahliannya. Dalam menempatkan tenaga kerja dalam satu tugas dan pekerjaan pimpinan tenaga kerja harus mempertimbangkan beberapa faktor yang mungkin sangat berpengaruh terhadap kelangsungan organisasi.

Masalah tenaga kerja bagi suatu organisasi merupakan salah satu bagian penting untuk keberhasilan dalam mencapai tujuan tersebut. Sebagaimana kita ketahui untuk meningkatkan produktivitas kerja tidak hanya tergantung pada mesin-mesin modern, modal yang besar, bahan, baku, tetapi juga tergantung pada orang yang melakukan aktivitas tersebut. Oleh sebab itu selayaknya organisasi memperhatikan faktor tenaga kerja ini, dimana pimpinan organisasi harus dapat 
memperhatikan kemampuan dan keahlian tenaga kerja sebagai pelaksana kegiatan dalam pencapaian tujuan organisasi. Berdasarkan hal tersebut guna meningkatkan produktivitas kerja, karyawan organisasi perlu mempunyai sistem dan kebijaksanaan dalam pelaksanaan perekrutan, seleksi dan penempatan tenaga kerja.

Penerapan sistem atau

kebijaksanaan organisasi baik dalam pelaksanaan perekrutan, seleksi dan khususnya dalam penempatan tenaga kerja yang tepat pada posisi yang tepat dan dirancang dapat mencapai daya guna dan hasil guna yang sebesarbesarnya sesuai dengan rencana yang telah ditetapkan sebelumnya. Dengan penempatan tenaga kerja yang tepat diharapkan dapat menumbuhkan motivasi kerja karyawan dalam meningkatkan produktivitasnya.

PT. Sindang Brothers Kota Lubuklinggau yang mulai dibentuk pada 11 Nopember 1991, berdasarkan Akta Notaris Ida Kesuma, SH nomor 13. Adapun jumlah karyawan administrasi yang berkantor di. PT. Sindang Brothers Kota Lubuklinggau sebanyak 47 orang terhitung bulan Nopember 2014. Perusahaan ini bergerak dalam bidang kontraktor perdagangan, suplayer dan rental seperti pemborongan/ kontraktor dalam pendirian/pembentulan bangunan, jalan, jembatan, irigasi dan pekerjaan lain dalam bidang pembangunan dan tekhnik umum. Perdagangan umum atas segala barang yang dapat diperdagangkan termasuk perdagangan impor dan ekspor, interinsuler/lokal baik atas perhitungan sendiri maupun atas perhitungan pihak lain secara komisi. Perindustrian dalam segala lapangan dan sektor perkebunan, pertanian, peternakan dan perikanan.

Berdasarkan hasil pengamatan yang dilakukan peneliti bahwa berkaitan dengan produktivitas kerja Karyawan
PT. Sindang Brothers Kota Lubuklinggau Dari segi Rekrutmen seperti Rekrutmen Karyawan belum sesuai dengan bagian yang ada, masih ada karyawan menduduki jabatan dan pekerjaan belum tepat dengan pendidikannya. Dari segi penempatan seperti penempatan karyawan masih belum sesuai dengan kompetensi dan kualifikasi, masih belum sesuai dengan pengalaman dan keterampilan yang dimiliki individu karyawan sehingga berpengaruh terhadap peningkatan produktivitas kerja para pegawai.

Produktivitas kerja karyawan secara garis besar merupakan cara kerja para karyawan, sampai dimana hasil kerja karyawan tersebut dalam megerjakan dan menyelesaikan tugastugasnya. Adapun yang dimaksud dengan suatu pekerjaan atau kerja adalah sejumlah rangkaian aktivitas jasmaniah dan rohaniah yang dilakukan oleh manusia untuk mencapai tujuan. Dengan demikian apabila dianalisis maka setiap kerja terdiri dari dua segi yaitu: segi dari aktivitasnya sendiri dan dari aktivitas yang dilakukan, secara sadar atau tidak pada dasarnya ditentukan oleh manusia itu sendiri.

Menurut Tohardi (dalam Sutrisno, 2009, h. 106) mengemukakan bahwa produktivitas kerja merupakan sikap mental. Sikap mental yang selalu mencari perbaikan terhadap apa yang telah ada.

Menurut Sutrisno (2009, h. 109) Produktivitas kerja terdiri dari tiga aspek yaitu pertama produktivitas adalah keluaran fisik per unit dari usaha produktif, kedua produktivitas merupakan tingkat keefektifan dari manajemen industri didalam penggunaan fasilitas-fasilitas untuk produksi dan ketiga produktifitas adalah keefektifan dari penggunaan tenaga kerja dan peralatan.Tetapi intinya semua mengarah pada tujuan yang sama 
bahwa produktivitas kerja adalah rasio dari hasil kerja dengan waktu yang dibutuhkan untuk menghasilkan produk dari seorang tenaga kerja.

Menurut J. Ravianto (2009, h. 112), produktivitas kerja adalah suatu konsep yang menunjang adanya keterkaitan hasil kerja dengan sesuatu yang dibutuhkan untuk menghasilkan produk dari tenaga kerja.

Rekrutmen merupakan proses komunikasi dua arah. organisasi sangat menginginkan informasi yang akurat tentang seperti apakah pelamar jikalau kelak dia diangkat sebagai pegawai.

Mangkunegara (2011:33) mengemukakan bahwa : "Penarikan adalah suatu proses atau tindakan yang dilakukan oleh perusahaan untuk mendapatkan tambahan pegawai yang melalui tahapan yang mencakup identifikasi dan evaluasi sumber-sumber penarikan pegawai, menentukan kebutuhan pegawai yang diperlukan perusahaan, proses seleksi, penempatan dan orientasi pegawai".

Deden Sutisna

menyebutkan bahwa "Rekrutmen merupakan proses mencari, menemukan dan menarik para pelamar untuk dikerjakan dalam suatu organisasi.

Menurut Noe at.all ( 2000, h.123 ) rekrutmen didefinisikan sebagai pelaksanaan atau aktifitas organisasi awal dengan tujuan untuk mengidentifikasi dan mencari tenaga kerja yang potensial. Proses rekrutmen dimulai ketika para pelamar dicari dan berakhir ketika lamaran mereka diserahkan. Agar efektifitas dan efisiensi organisasi terwujud diperlukan proses rekrutmen yang tepat dengan dilandasi perencanaan yang matang.

Penelitian Purwati dan Satria (2018) menunjukkan bahwa perekrutan memiliki peranan penting dalam nantinya menunjang kinerja yang dihasilkan oleh karyawan. Untuk itu perlu adanya system perekrutan yang sesuai antara kualifikasi calon pekerja dan pekerjaan yang akan diberikan nantinya.

Adapun kerangka pemikiran dalam penelitian ini dapat dilihat pada gambar berikut ini :

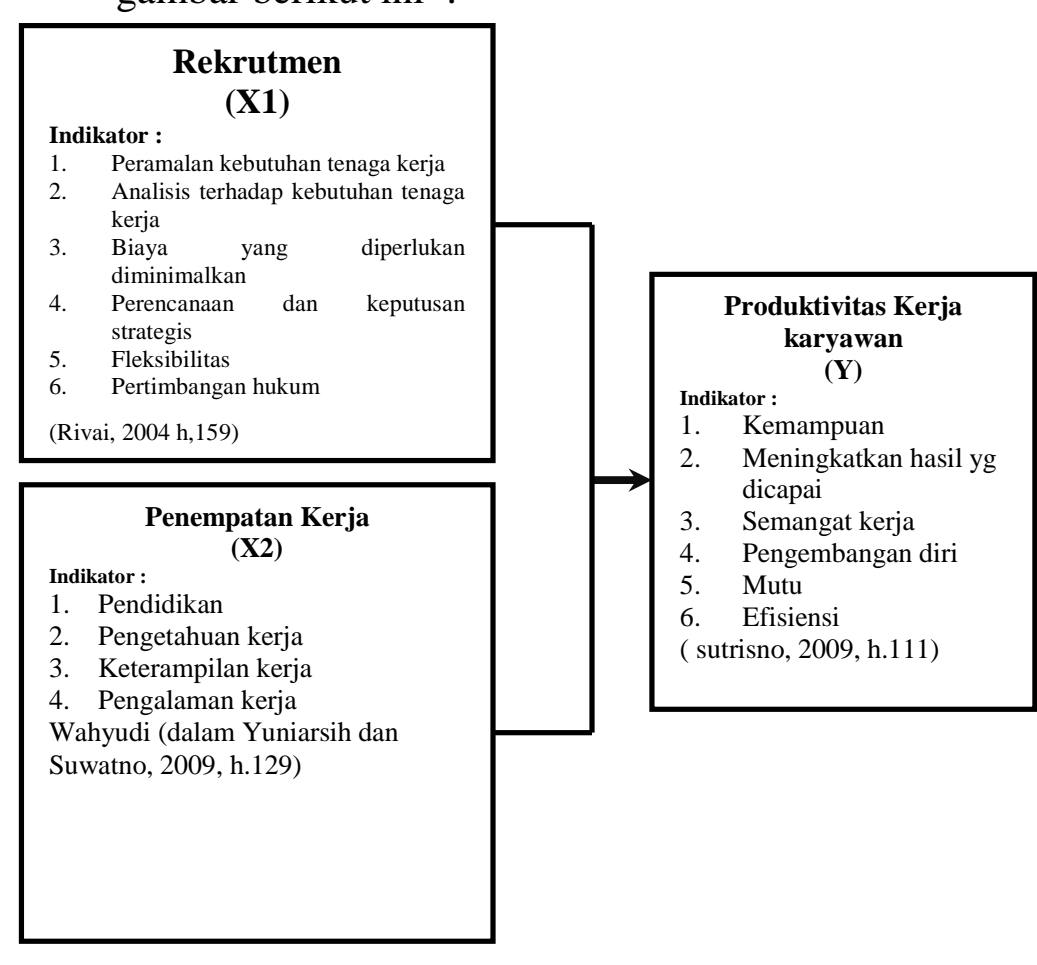

\section{Gambar 1. Kerangka Pemikiran}

\section{METODE PENELITIAN Variabel Penelitian}

Yang menjadi variabel dalam penelitian ini adalah :

a. Rekrutmen $\left(\mathrm{X}_{1}\right)$ : Rekrutmen didefinisikan sebagai pelaksanaan atau aktifitas organisasi awal dengan tujuan untuk mengidentifikasi dan mencari tenaga kerja yang potensial.Proses rekrutmen dimulai ketika para pelamar dicari dan berakhir ketika lamaran mereka diserahkan. Agar efektifitas dan efisiensi organisasi terwujud diperlukan proses rekrutmen yang tepat dengan dilandasi perencanaan yang matang. 
b. Penempatan Kerja $\left(\mathrm{X}_{2}\right)$ : Penempatan kerja adalah tindak lanjut dari seleksi, yaitu menempatkan calon karyawan yang diterima pada jabatan/pekerjaan yang dibutuhkannya dan sekaligus mendelegasikan authority kepada orang tersebut

c. Produktivitas kerja (Y) : Produktivitas kerja adalah suatu konsep yang menunjang adanya keterkaitan hasil kerja dengan sesuatu yang dibutuhkan untuk menghasilkan produk dari tenaga kerja.

\section{Populasi dan Sampel \\ Populasi}

Populasi adalah wilayah generalisasi yang terdiri atas objek yang mempunyai kualitas dan karakteristik tertentu yang ditetapkan oleh peneliti untuk dipelajari dan kemudian ditarik kesimpulannya. (Sugiyono, 2009; h.115 ) Populasi dalam penelitian ini adalah seluruh jumlah Karyawan administrasi yang berkantor pada Kantor PT. Sindang Brothers Kota Lubuklinggau sebanyak 47 orang yang terdiri dari staf Mekanik 13 Orang, staf Basecamp 8 Orang, staf Stone Cruser 5 Orang, staf Operator 5 Orang, staf Personel administrasi 16 Orang.

\section{Sampel}

Sampel adalah bagian dari jumlah dan karakteristik yang dimiliki oleh populasi tersebut (Sugiyono, 2009, h.116). Dalam penelitian ini seluruh populasi dijadikan sampel (sampel jenuh) berjumlah 47 orang

\section{Teknik Pengumpulan Data}

Teknik pengumpulan data yang digunakan pada penelitian ini adalah

a. Observasi

Yaitu pengamatan secara langsung ke Kantor PT. Sindang Brothers Kota Lubuklinggau untuk mengamati masalah-masalah yang berhubungan dengan objek yang sedang diteliti.

b. Dokumentasi

Dokumentasi adalah suatu cara untuk memperoleh data atau informasi mengenai hal-hal atau variabel yang ada kaitannya dengan penelitian yang berupa cacatan, transkip, buku, surat kabar, majalah, notulen rapat, agenda, dan sebagainya

c. Kuisioner

Yaitu teknik pengumpulan data melalui penyebaran kuisioner yang berisikan pertanyaan-pertanyaan yang ada hubungannya dengan variabel yang akan diteliti pada Karyawandan pimpinanPT. Sindang Brothers Kota Lubuklinggau.

\section{Uji Validitas dan Realibilitas}

\section{a. Uji Validitas}

Husaini Usman (2006,h.287) menyatakan Validitas ialah mengukur apa yang ingin diukur. Uji validitas adalah untuk mengetahui kevalidan dari intrument (kuisoner) yang digunakan dalam pengumpulan data. Uji ini dilakukan untuk mengetahui apakah item-item yang tersaji dalam kuisoner benar-benar mampu mengungkapkan dengan pasti apa yang akan diteliti.

Menurut Sugiyono (2004, h.138) cara yang digunakan adalah dengan analisa item, dimana setiap nilai yang ada setiap butir pertanyaan dikorelasikan dengan total nilai seluruh butir pertanyaan untuk satu variabel dengan menggunakan rumus korelasi Product Moment. Syarat minimum untuk dianggap valid adalah nilai rhitung >dairtabel. Uji Validitas dilakukan di PT. Sindang brothers

\section{b. Uji Reliabilitas}

Sedangkan uji reliabilitas dimaksudkan untuk mengetahui adanya konsistensi alat ukur dalam 
penggunaannya, atau dengan kata lain alat ukur tersebut mempunyai hasil yang konsisten apabila digunakan berkali-kali pada waktu yang berbeda.

Menurut Arikunto (2002, h.145) untuk uji reliabilitas digunakan teknik Alpha Cronbach, dimanasuatu instrument dapat dikatakan handal (reliabel) bila memiliki koefisien keandalan atau alpha sebesar 0,6 atau lebih.

Pada penelitian ini perhitungan reliabilitas menggunakan rumus alpha (Arikunto, 2002, h.138) sebagai berikut

$$
r_{11}=\left(\frac{k}{k-1}\right)\left(1-\frac{\sum o b^{2}}{o t^{2}}\right)
$$

Dimana :

$\mathrm{r}_{11}=$ Reliabilitas instrument

$\mathrm{K}$ = Banyaknya butir pertanyaan

$\mathrm{ob}^{2}=$ Jumlah varians butir

$\mathrm{ot}^{2}=$ Jumlah varians total

\section{Uji Asumsi Klasik}

\section{a. Uji Normalitas}

Tujuan uji normalitas adalah untuk mengetahui apakah distribusi sebuah data atau mendekati distribusi normal, yaitu distribusi data dengan bentuk

lonceng (bell shapped). Data yang baik adalah data yang mempunyai pola seperti distribusi normal. Uji normalitas ini dilakukan dengan memakai uji Kolmogorov Smirnov, dimana data mendekati atau berdistribusi normal dapat dilihat dari : (1) nilai Sig. atau signifikan atau probabilitas < 0,05 maka distribusi sebuah data adalah tidak normal, (2) nilai Sig. atau signifikan atau probabilitas > 0,05 maka distribusi data adalah normal (Sugiyono, 2007, h. 235).

\section{Teknik Analisa Data}

Teknik yang digunakan dalam menganalisis permasalahan yang ada dalam penelitian ini yaitu :

\section{a. Regresi Linear Berganda}

Analisis Regresi Linear Berganda, untuk mengetahui pengaruh Rekrutmen $\left(\mathrm{X}_{1}\right)$ dan penempatan Kerja $\left(\mathrm{X}_{2}\right)$ secara keseluruhan terhadap produktivitas kerja Karyawan (Y) pada PT. Sindang Brothers Kota Lubuklinggau.

$$
\hat{Y}=\mathrm{a}+\mathrm{b}_{1} \mathrm{X}_{1}+\mathrm{b}_{2} \mathrm{X}_{2}
$$

(Riduwan dan Sunarto, 2009,h.109)

Dimana :

$\hat{Y}=$ Produktivitas kerja Karyawan

$\mathrm{X}_{1}=$ Rekrutmen

$\mathrm{X}_{2}=$ Penempatan Kerja

$\mathrm{a}=$ Konstanta

$b_{1}, b_{2}=$ Koefisien Regresi

\section{b. Analisis Koefisien Korelasi}

Koefisein determinasi digunakan untuk mengetahui persentase pengaruh semua variabel bebas terhadap variabel terikat dengan rumus sebagai berikut:

$$
R^{2}=\frac{b 1 \sum X_{1} Y+b 2 \sum X_{2} Y}{\sum Y^{2}}
$$

Dimana:

$\mathrm{R}^{2} \quad=$ Koefisiensi Determinasi

$\mathrm{b}_{1}, \mathrm{~b}_{2}=$ Koefisien Regresi

$\mathrm{X}_{1}=$ Rekrutmen

$\mathrm{X}_{2}=$ PenempatanKerja

$\mathrm{Y}=$ Produktivitas kerja Karyawan Uji F

Untuk mengetahui pengaruh signifikan rekrutmen dan penempatan kerja secara keseluruhan terhadap produktivitas kerja karyawan pada PT. Sindang Brothers Kota Lubuklinggau.

Rumus : $\quad \mathrm{F}_{\text {hitung }}=\frac{R^{2}(n-m-1)}{m\left(1-R^{2}\right)}$

(Riduwan dan Sunarto, 2009,h.110)

Dimana :
$\mathrm{R}^{2} \quad$ : Nilai Regresi
$\mathrm{k}$ : Banyaknya variable bebas
$\mathrm{n} \quad$ : Jumlah sampel 
Uji F melalui prosedur sebagai berikut : $\mathrm{H}_{\mathrm{o}}: \rho=0$, menunjukkan bahwa Rekrutmen dan penempatan Karyawantidak $\begin{array}{lr}\text { berpengaruh } & \text { terhadap } \\ \text { produktivitas } & \text { kerja }\end{array}$ KaryawanpadaPT. Sindang Brothers Kota Lubuklinggau.

$\mathrm{H}_{\mathrm{a}}: \rho \neq 0$, menunjukkan bahwa Rekrutmen dan penempatan

Karyawanberpengaruh terhadap produktivitas kerja KaryawanpadaPT. Sindang Brothers Kota Lubuklinggau.

Dikatakan signifikan jika $\mathrm{F}_{\text {hitung }}>$ $\mathrm{F}_{\text {tabel}}$, ini berarti $\mathrm{H}_{\mathrm{o}}$ ditolak dan $\mathrm{H}_{\mathrm{a}}$ diterima dan sebaliknya jika $\mathrm{F}_{\text {hitung }}<$ $\mathrm{F}_{\text {tabel}}$, berarti $\mathrm{H}_{\mathrm{o}}$ diterima dan $\mathrm{H}_{\mathrm{a}}$ ditolak.

\section{HASIL DAN PEMBAHASAN Uji Validitas dan Reliabilitas}

1. Hasil Uji Validitas

Untuk pengujian validitas tiap butir digunakan analisis item, yaitu mengkorelasikan skor tiap butir dengan skor total yang merupakan jumlah tiap skor butir. Adapun kriteria penilaian yaitu item pertanyaan dianggap valid jika nilai validitasnya lebih besar dari nilai korelasi product moment tabel pada tingkat signifikasi 0,05 dan jumlah sampel $25=30$, maka diperoleh nilai $r$ tabel yakni sebesar 0,396.Kuisioner diberikan kepada Karyawan CV. Alan Brothers Kota Lubuklinggau.

Dalam pengujianvaliditas ini, peneliti menggunakan bantuan program SPSS for Windows 17.0 dimana untuk analisis dilakukan dengan cara membandingkan nilai $\mathrm{r}$ hitung (CITC)

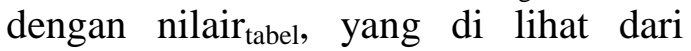
(output view) mengenai Item-total Statistics "Corrected Item-Total Correlation", dimana suatu butir pertanyaan akan dianggap valid atau sah jika $\mathrm{r}_{\text {hitung }}(C I T C)$ lebih besar darir ${ }_{\text {tabel. }}$

Dari uji validitas di atas, sampel yang dipakai 25 responden, semua variabel mempunyai koefisien CITC. Untuk tingkat signifikan 5\%, dan kriteria perhitungan $r_{\text {tabel }} \mathrm{n}=25$, sehingga diperoleh $r_{\text {tabel }}$ sebesar 0,396. Berdasarkan hasil perhitungan di atas maka dengan koefisien korelasi $\mathrm{r}_{\text {hitung }}$ (CITC) $\geq r_{\text {tabel, }}$ pada tingkat signifikan $5 \%$, oleh karena itu dapat disimpulkan bahwa butir pertanyaan mengenai Rekrutmendapat dinyatakan valid atau sah digunakan untuk instrumen penelitian selanjutnya.

Berdasarkan hasil perhitungan di atas, maka dengan koefisien korelasi $\mathrm{r}_{\text {hitung }} \quad$ (CITC) $\geq \mathrm{r}_{\text {tabel, }}$ pada tingkat signifikan $5 \%$, oleh karena itu dapat disimpulkan bahwa butir pertanyaan mengenai Penempatan Kerja dapat dinyatakan valid atau sah digunakan untuk instrumen penelitian selanjutnya Berdasarkan hasil perhitungan di atas, maka dengan koefisien korelasi $\mathrm{r}_{\text {hitung }} \quad(\mathrm{CITC}) \geq \mathrm{r}_{\text {tabel, }}$ pada tingkat signifikan $5 \%$, oleh karena itu dapat disimpulkan bahwa butir pertanyaan mengenai Produktivitas Kerja dapat dinyatakan valid atau sah digunakan untuk instrumen penelitian selanjutnya

\section{Hasil Uji Reliabilitas}

Untuk menentukan reliabel dan tidaknya suatu instrumen penelitian umumnya adalah perbandingan antara nilai $r_{\text {hitung }}$ dengan $r_{\text {tabel }}$ pada taraf kepercayaan $95 \%$ atau tingkat signifikansi $5 \%$. Apabila dilakukan pengujian reliabilitas dengan metode Alpha cronbach, maka nilai $\mathrm{r}$ hitung diwakili oleh nilai alpha.

Suatu butir akan dikatakan reliabel apabila nilai koefisien Cronbach alphalebih besar dari nilai $r_{\text {tabel }}$ dengan tingkat signifikan $5 \%$, dan kriteria perhitungan $r_{\text {tabel }} \mathrm{n}=25$, maka 
diperoleh nilai $r_{\text {tabel }}=0,396$. Hasil uji reliabilitas untuk variabel dapat ditunjukkan pada tabel 1 :

Tabel 1. Hasil Uji Validitas dan Reliabilitas

\begin{tabular}{cccc}
\hline VARIABEL & CRONBACH ALPHA & RTABEL & KESIMPULAN \\
\hline Rekrutmen & 0,808 & 0,396 & Reliabel \\
Penempatan & 0,792 & 0,396 & Reliabel \\
Produktipitas & 0,861 & 0,396 & Reliabel
\end{tabular}

Sumber : Data hasil penelitian diolah, 2015

Dari uji reliabilitas di atas, semua nilai koefisien Cronbachalpha $\geq$ $r_{\text {tabel. }}$. Untuk tingkat signifikan $5 \%$, dan kriteria perhitungan $r_{\text {tabel }} \mathrm{n}=25$, sehingga diperoleh $r_{\text {tabel }}$ sebesar 0,396 . Berdasarkan hasil perhitungan tersebut, maka dengan koefisien Cronbachalpha masing-masing variabel baik Rekrutmen, Penempatan Kerja dan Produktivitas Kerja $\geq r$ tabel (0,396), maka kuesioner sebagai alat pengukur dalam penelitian ini telah memenuhi syarat reliabilitas.

\section{Uji Asumsi Klasik}

Peneliti dalam penelitian ini menggunakan statistik untuk pengolahan datanya, maka perlu dilakukan berbagai uji untuk membuktikan bahwa tidak terjadi berbagai macam pelanggan pelanggaran yang dapat menyebabkan hasil penelitian akan tampak bias. Dikarenakan teknis analisis data menggunakan Analisis Regresi Berganda, maka peneliti melakukan Uji Asumsi Klasik (Uji Normalitas Uji Multikolinear dan Uji Liniearitas).

Berikut di bawah ini adalah Uji Asumsi Klasik pada variabel motivasi $\left(\mathrm{X}_{1}\right)$, Kepemimpinan $\left(\mathrm{X}_{2}\right)$ dan kinerja $(\mathrm{Y})$ dengan menggunakan SPSS 22.

a. Uji Normalitas

Uji normalitas merupakan suatu bentuk distribusi Frekuensi yang memenuhi ciri-ciri kurva normal yang berbentuk seperti lonceng (bell shaped), bentuknya tergantung pada dua parameter yaitu rerata dan standar deviasi, dengan luas wilayah kurva normal $100 \%$.
Uji normalitas bisa dilakukan dengan dua cara. Yaitu dengan "Normal P-P Plot" dan "Tabel Kolmogorov Smirnov". Yang paling umum digunakan adalah Normal P-P Plot. Pada Normal P-P Plot prinsipnya normalitas dapat dideteksi dengan melihat penyebaran data(titik) pada sumbu diagonal grafik atau dengan melihat histogram dari residualnya. Dasar pengambilan keputusan:

1. Jika data menyebar di sekitar garis diagonal dan mengikuti arah garis diagonal atau grafik histogramnya menunjukan pola distribusi normal, maka model regresi memenuhi asumsi normalitas.

2. Jika data menyebar jauh dari garis doagonal dan/atau tidak mengikuti arah garis diagonal atau grafik histogram tidak menunjukan pola distribusi normal, maka model regresi tidak memenuhi asumsi normalitas, Imam Ghozali (dalam artikel Sisca,h.110112).

Pada uji normalitas sebaran, data yang di ambil telah mengikuti distribusi normal. Distribusi normal ditandai dengan output histogram tampak bahwa tiap data menyebar ke seluruh daerah normal. Daerah normal itu sendiri adalah daerah yang berada di bawah kurva tersebut yang bentuknya seperti lonceng terbalik.



Sumber : Hasil Olahan Data, 


\section{Gambar 2 Hasil Ujia Normal (Histogram)}

Data berdistribusi normal juga terbukti pada output gamabr 2 hasil Normal P-P Plot. Titik-titik menyebar sepanjang garis regresi. Hal tersebut mengartikan sebaran datanya merata sehingga dapat dihasilkan $\mathrm{Y}$ yang merata pula pada garis Regresi.

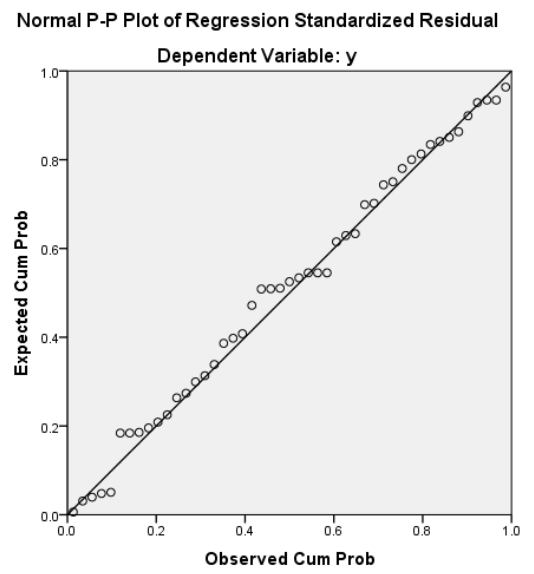

Sumber : Hasil Olahan Data Tahun 2015

\section{Gambar 3 : Hasil Uji Normalitas} (Normal P-P Plot)

Dari analisis kurva dapat dilihat bahwa data menyebar disekitar diagram dan mengikuti model regresi sehingga dapat disimpulkan bahwa data yang diolah merupakan data yang berdistribusi normal sehingga uji normalitas terpenuhi.

Pada uji Kolmogorov Smirnov sehingga hasilnya dapat ditentukan bahwa data mempunyai distribusi normal atau tidak. Data dikatakan normal jika nilai signifikan $(>0.005)$.

Tabel 2. Hasil Uji Kolmogorov Smirnov

\begin{tabular}{llr}
\hline \multicolumn{3}{c}{ One-Sample Kolmogorov-Smirnov Test } \\
\hline & & \multicolumn{2}{c}{$\begin{array}{c}\text { Unstandardized } \\
\text { Residual }\end{array}$} \\
\hline $\mathrm{N}$ & Mean & 47 \\
\cline { 2 - 3 } Normal & Std. Deviation & .0000000 \\
Parameters & a,b & 4.24654889 \\
\hline Most Extreme & Absolute & .083 \\
\cline { 2 - 3 } Differences & Positive & .060 \\
\cline { 2 - 3 } & Negative & -.083 \\
\hline
\end{tabular}

\begin{tabular}{lr}
\hline Test Statistic & .083 \\
\hline Asymp. Sig. (2-tailed) & $.200^{\mathrm{c}, \mathrm{d}}$ \\
\hline a. Test distribution is Normal. & \\
\hline b. Calculated from data. & \\
\hline c. Lilliefors Significance Correction. &
\end{tabular}

Sumber : Hasil Olahan Data, Tahun 2015

Untuk menganalisisnya, dilihat pada baris "Asymp.sig.(2-tailed)" baris paling bawah. Bila nilai signifikan tiap variabel lebih dari (>0.005) maka uji normalitas bisa terpenuhi. Berdasarkan hasil uji normalitas menunjukan bahwa nilai signifikan (0.005) sehingga data dapat dikatakan normal. Pada tabel 4.37 nilai signifikan "Asimp.sig. (Tailed)" Lebih dari $(>0.05)$. jadi dapat disimpulkan bahwa uji normalitasnya terpenuhi.

\section{Perhitungan Regresi Linier Berganda}

Metode regresi linear berganda digunakan dengan tujuan untuk mencari hasil dari penyebaran kuesioner yang dilakukan terhadap 47 orang responden pada Karyawan PT. Sindang Brothers Kota Lubuklinggau.Dari hasil tersebut diperoleh jawaban mengenai pengaruh Penempatan Kerja dan Rekrutmen terhadap Produktivitas KerjaKaryawan PT. Sindang Brothers Kota Lubuklinggau.

Untuk metode pengujian regresi yang dilakukan pada penelitian ini menggunakan metode enter (method enter), dimana semua variabel independen yang ada dimasukkan untuk analisis regresi secara bersama-sama dan tidak ada variabel independen yang dikeluarkan. Adapun hasil metode pengujian regresi yang dilakukan dapat dilihat pada tabel di bawah ini: 
Tabel 3

Metode Pengujian Regresi

\begin{tabular}{llll}
\hline \multicolumn{4}{c}{ Variables Entered/Removed } \\
\hline Model & \multicolumn{1}{c}{ Variables Entered } & $\begin{array}{l}\text { Variables } \\
\text { Removed }\end{array}$ & Method \\
\hline 1 & $\begin{array}{l}\text { Rekrutmen, } \\
\text { Penempatan Kerja }\end{array}$ & . Enter \\
& & \\
\hline a. All requested variables entered. & \\
\hline
\end{tabular}

Sumber : Data hasil penelitian diolah, 2015

Dari tabel di atas menunjukkan bahwa, dengan menggunakan metode enter (method enter) semua variabel independen yang ada dimasukkan secara bersama-sama kedalam pengujian regresi dan tidak ada salah satu variabel yang dikeluarkan. Sedangkan untuk hasil pengujian regresi yang dilakukan dapat dilihat pada tabel 4:

Tabel 4

Hasil Uji Regresi Linear Berganda

\begin{tabular}{|c|c|c|c|c|c|}
\hline \multicolumn{6}{|c|}{ Coefficients $^{\mathrm{a}}$} \\
\hline \multirow[b]{2}{*}{ Model } & $\begin{array}{r}\text { Unsta } \\
\text { Coe }\end{array}$ & $\begin{array}{l}\text { dardized } \\
\text { ficients }\end{array}$ & $\begin{array}{c}\text { Standardiz } \\
\text { ed } \\
\text { Coefficient } \\
\text { s } \\
\end{array}$ & \multirow[b]{2}{*}{$\mathrm{T}$} & \multirow[b]{2}{*}{ Sig. } \\
\hline & B & Std. Error & Beta & & \\
\hline $1 \quad$ (Constant) & 20.583 & 6.853 & & 3.003 & .004 \\
\hline $\mathrm{X} 1$ & .161 & .132 & .179 & 2.116 & .230 \\
\hline $\mathrm{X} 2$ & .230 & .146 & .231 & 2.373 & .123 \\
\hline
\end{tabular}

a. Dependent Variable: Y \begin{tabular}{llr}
\multicolumn{1}{c}{ Dari hasil pengolahan data } \\
dengan & bantuan & komputer \\
menggunakan program SPSS 17.0 for
\end{tabular} menggunakan program SPSS 17.0 for
windows, dapat diketahui hasil pengujian regresi berganda diperoleh persamaan sebagai berikut :

$$
Y=10.726+0,326 X_{1}+0,403 X_{2}
$$

Persamaan regresi tersebut memperlihatkan bahwa seluruh koefisien regresi bertanda positif, hal ini berarti bahwa variabel independen mempunyai pengaruh searah dengan variabel dependen, artinya apabila nilai dari variabel independen meningkat atau menurun, maka akan mendorong naik atau turunnya Produktivitas Kerja. Untuk lebih memperjelas persamaan tersebut, maka dari persamaan regresi dapat diterangkan sebagai berikut :
1. Nilai konstanta yaitu sebesar 10,726. Hal ini menunjukkan bahwa jika Rekrutmen dan Penempatan Kerja pada Karyawan PT. Sindang Brothers Kota Lubuklinggau semakin baik, maka kepuasan pelanggan akan meningkat sebesar 10,726 atau dapat dikatakan bahwa Rekrutmen dan Penempatan Kerja berpengaruh terhadap peningkatan Produktivitas Kerja, dan sebaliknya jika Rekrutmen dan Penempatan Kerja buruk maka Produktivitas Kerja akan menurun.

2. Nilai koefisien regresi variabel Rekrutmen sebesar 0,326. Hal ini menunjukkan bahwa setiap adanya peningkatan Rekrutmen pada Karyawan PT. Sindang Brothers Kota Lubuklinggau, sebesar 1 satuan atau $100 \%$, maka hal tersebut akan meningkatkan Produktivitas Kerja pada Karyawan PT. Sindang Brothers Kota Lubuklinggau sebesar 0,326, demikian sebaliknya.

3. Nilai koefisien regresi variabel Penempatan Kerja sebesar 0,403 hal ini menunjukkan bahwa setiap adanya peningkatan Penempatan Kerja pada Karyawan PT. Sindang Brothers Kota Lubuklinggau sebesar 1 satuan atau $100 \%$, maka hal tersebut akan meningkatkan Produktivitas Kerja pada Karyawan PT. Sindang Brothers Kota Lubuklinggau sebesar 0,403, demikian sebaliknya.

\section{Analisis Koefisien Korelasi}

Uji determinasi dilakukan untuk menyatakan besar kecilnya konstribusi (sumbangan) variabel (X) terhadap variabel (Y) atau koefesien determinan $\left(\mathrm{R}_{\text {Square }} / \mathrm{R}^{2}\right.$.). Untuk melihat besarnya pengaruh variabel Rekrutmendan Penempatan Kerja terhadap variabel 
Produktivitas Kerja, terlihat pada tabel 5:

Tabel 5.

Hasil Uji Determinasi

\begin{tabular}{lrrrr}
\hline \multicolumn{5}{c}{ Model Summary $^{\mathbf{b}}$} \\
\hline Model & $\mathrm{R}$ & R Square & $\begin{array}{r}\text { Adjusted } \\
\text { R Square }\end{array}$ & $\begin{array}{c}\text { Std. Error of the } \\
\text { Estimate }\end{array}$ \\
\hline 1 & $\begin{array}{r}.326 \\
\mathrm{a}\end{array}$ & .106 & .065 & 4.342
\end{tabular}

a. Predictors: (Constant), X2, X1

b. Dependent Variable: Y

Sumber : Data hasil penelitian diolah, 2015

Dari hasil perhitungan koefisien korelasi di atas, bahwa besarnya konstribusi (sumbangan) variabel Rekrutmen dan Penempatan Kerja terhadap variabel kepuasan pelanggan, dilihat dari nilai koefesien determinasi $\left(\mathrm{R}_{\text {Square }} / \mathrm{R}^{2}\right)$ yang diperoleh dari hasil pengolahan dengan program SPSS 17.0 for windows adalah sebesar 0,326. Dengan demikian menunjukkan bahwa sebesar 51,9\% variabel Produktivitas Kerja dapat dijelaskan oleh variabel Rekrutmen dan Penempatan Kerja, sedangkan sisanya sebesar 49,1\% dijelaskan oleh variabel lain yang tidak diteliti.

\section{Uji t (Parsial)}

Untuk melihat pengaruh parsial dari masing-masing variabel bebas terhadap variabel terikat dapat dijelaskan dengan menggunakan uji t, hasil uji t secara rinci disajikan pada tabel dibawah ini:

Tabel 7. Hasil Uji t (Parsial)

\begin{tabular}{|c|c|c|c|c|c|}
\hline \multicolumn{6}{|c|}{ icients ${ }^{\mathrm{a}}$} \\
\hline \multirow[b]{2}{*}{ Model } & $\begin{array}{r}\text { Unstand } \\
\text { Coeffi }\end{array}$ & $\begin{array}{l}\text { Irdized } \\
\text { ients }\end{array}$ & $\begin{array}{l}\text { Standardized } \\
\text { Coefficients }\end{array}$ & & \\
\hline & B & $\begin{array}{l}\text { Std. } \\
\text { Error }\end{array}$ & Beta & $\mathrm{T}$ & Sig.K \\
\hline $\begin{array}{ll}1 & \text { (Constan } \\
\text { t) }\end{array}$ & 20.583 & 6.853 & & 3.003 & .002 . \\
\hline $\mathrm{X} 1$ & .161 & .132 & .179 & 2.116 & .004 \\
\hline $\mathrm{X} 2$ & .230 & .146 & .231 & 2.373 & .001 \\
\hline
\end{tabular}

Berdasarkan rekapitulasi hasil uji t diatas dapat dijelaskan, bahwa:

a. Variabel Rekrutmen $\left(\mathrm{X}_{1}\right)$ terhadap produktivitas kerja menunjukkan nilai $t_{\text {hitung }}=2,116$ lebih besar dari $t_{\text {tabel }}$ $(1,6779)$ dengan taraf signifikansi 0,004 , hal ini berarti bahwa secara parsial variabel rekrutmen memiliki pengaruh yang signifikan terhadap produktivitas kerja karyawan pada PT. Sindang Brothers Kota Lubuklinggau. Hal ini membuktikan bahwa hipótesis pertama yang berbunyi "Terdapat pengaruh rekrutmen terhadap produktivitas kerja karyawan PT. Sindang Brothers Kota Lubuklinggau"

b. Variabel Penempatan Kerja $\left(\mathrm{X}_{2}\right)$ terhadap produktivitas kerja menunjukkan nilai $t_{\text {hitung }}=2,373$ lebih besar dari $t_{\text {tabel }}(1,6779)$ dengan taraf signifikansi 0,001 , hal ini berarti bahwa secara parsial variabel penempatan kerja memiliki pengaruh yang signifikan terhadap produktivitas kerja karyawan pada PT. Sindang Brothers Kota Lubuklinggau. Hal ini membuktikan bahwa hipótesis kedua yang berbunyi "Terdapat pengaruh penempatan kerja terhadap produktivitas kerja karyawan PT. Sindang Brothers Kota Lubuklinggau"

\section{Hasil Uji Statistik (Uji F )}

\section{Hipotesis :}

$\mathrm{H}_{\mathrm{o}}=$ Tidak Terdapat pengaruh signifikan Rekrutmen dan Penempatan Kerja terhadap Produktivitas Kerjapada PT. Sindang Brothers Kota Lubuklinggau.

$\mathrm{H}_{\mathrm{a}}=$ Terdapat pengaruhsignifikan Rekrutmen dan Penempatan Kerjaterhadap Produktivitas KerjapadaPT. Sindang Brothers Kota Lubuklinggau.

Jika $F_{\text {hitung }} \geq \mathrm{F}_{\text {tabel }}$ atau signifikan $\leq$ $\alpha$, maka $\mathrm{H}_{\mathrm{o}}$ ditolak dan $\mathrm{H}_{\mathrm{a}}$ diterima, artinya terdapat pengaruh Rekrutmendan Penempatan Kerjaterhadap Produktivitas Kerja 
padaKaryawan PT. Sindang Brothers Kota Lubuklinggau.

2. Jika $F_{\text {hitung }}<F_{\text {tabel }}$ atau signifikan $>$ $\alpha$, maka $\mathrm{H}_{\mathrm{o}}$ diterima dan $\mathrm{H}_{\mathrm{a}}$ ditolak, artinya tidak terdapatRekrutmen dan Penempatan Kerjaterhadap Produktivitas Kerja padaKaryawan PT. Sindang Brothers Kota Lubuklinggau.

\section{Tabel 8.}

Hasil Uji F

\begin{tabular}{|c|c|c|c|c|c|c|}
\hline \multicolumn{7}{|c|}{ ANOVA $^{\mathrm{a}}$} \\
\hline \multicolumn{2}{|c|}{ Model } & $\begin{array}{l}\text { Sum of } \\
\text { Squares }\end{array}$ & Df & $\begin{array}{c}\text { Mean } \\
\text { Square }\end{array}$ & $\mathrm{F}$ & Sig. \\
\hline \multirow[t]{3}{*}{1} & Regression & 98.431 & 2 & 49.216 & 2.611 & $.085^{\mathrm{b}}$ \\
\hline & Residual & 829.526 & 44 & 18.853 & & \\
\hline & Total & 927.957 & 46 & & & \\
\hline \multicolumn{7}{|c|}{ a. Dependent Variable: Y } \\
\hline \multicolumn{7}{|c|}{ b. Predictors: (Constant), X2, X1 } \\
\hline
\end{tabular}

Berdasarkan tabel di atas, hasil pengujian dengan SPSS 17.0 for windows yang dilakukan, nilai $\mathrm{F}_{\text {hitung }}$ yang diperoleh sebesar 49,216 dan sig. 0,85 . Hal ini berarti $F_{\text {hitung }}>F_{\text {tabel }}$ atau nilai sig. 0,85 lebih kecil dari tingkat signifikan $(\propto)$ 0,05. Dengan demikian berdasarkan kriteria pengujian hipotesis, jika $F_{\text {hitung }} \geq \mathrm{F}_{\text {tabel }}$ berarti $\mathrm{H}_{\mathrm{o}}$ ditolak dan $\mathrm{H}_{\mathrm{a}}$ diterima. Sementara itu nilai $\mathrm{F}_{\text {hitung }}$ yang diperoleh sebesar 49,216 dan signifikan 0,85 . Hal ini berarti $F_{\text {hitung }}$ $>F_{\text {tabel }}$ atau nilai sig. 0,85 lebih kecil dari tingkat signifikan $(\propto) \quad 0,05$. Hal tersebut juga menggambarkan bahwa adanya pengaruh yang signifikan, sehingga dapat dikatakan bahwa Rekrutmen dan Penempatan Kerja berpengaruh secara signifikan terhadap Produktivitas KerjapadaPT. Sindang Brothers Kota Lubuklinggau.

Hasil penelitian menunjukkan bahwa Rekrutmen dan Penempatan Kerja berpengaruh terhadap Produktivitas Kerja pada Karyawan PT. Sindang Brothers Kota Lubuklinggau. Untuk besarnya pengaruh antara variabel Rekrutmen dan Penempatan Kerja terhadap Produktivitas Kerjadapat dilihat dari nilai koefisien determinasi
$\left(\mathrm{R}_{\text {Square }} / \mathrm{R}^{2}\right)$ yang diperoleh sebesar 0,519 . Dengan demikian menunjukkan bahwa sebesar 51,9\% variabel Produktivitas Kerjadapat dijelaskan oleh variabel Rekrutmen dan Penempatan Kerja, sedangkan sisanya sebesar $49,1 \%$ dijelaskan oleh variabel lain yang tidak diteliti. Dengan melihat hasil koefesien determinasi yang diperoleh dapat dikatakan juga bahwa nilai Rekrutmen dan Penempatan Kerja masih termasuk rendah sehingga perlu ditingkatkan, apalagi variabel Penempatan Kerja dalam pemasaran jasa khususnya memegang peranan yang penting dalam pemasaran, apalagi variabel Rekrutmen yang mana merupakan faktor yang pada umumnya paling diinginkan oleh konsumen, sebab dengan Rekrutmen yang baik biasanya pelanggan akan merasa puas atas produk atau jasa yang ditawarkan.

Demikian juga halnya jika dilihat dari hasil uji $\mathrm{F}$ menunjukkan bahwa terdapat pengaruh Rekrutmendan Penempatan Kerja secara bersama-sama terhadap Produktivitas Kerjahasil pengujian dengan SPSS 17.0 for windows yang dilakukan, nilai $\mathrm{F}_{\text {hitung }}$ yang diperoleh sebesar 49,216 dan sig. 0,85 . Hal ini berarti $F_{\text {hitung }}>F_{\text {tabel }}$ atau nilai sig. 0,85 lebih kecil dari tingkat signifikan $(\propto) 0,05$. Dengan demikian berdasarkan kriteria pengujian hipotesis, jika $F_{\text {hitung }} \geq F_{\text {tabel }}$ berarti $\mathrm{H}_{\mathrm{o}}$ ditolak dan $\mathrm{H}_{\mathrm{a}}$ diterima. Sementara itu nilai $\mathrm{F}_{\text {hitung }}$ yang diperoleh sebesar 49,216 dan signifikan 0,85 . Hal ini berarti $F_{\text {hitung }}$ $>\mathrm{F}_{\text {tabel }}$ atau nilai sig. 0,85 lebih kecil dari tingkat signifikan $(\propto) \quad 0,05$. Hal tersebut juga menggambarkan bahwa adanya pengaruh yang signifikan, sehingga dapat dikatakan bahwa Rekrutmen dan Penempatan Kerja berpengaruh secara signifikan terhadap Produktivitas KerjapadaPT. Sindang Brothers Kota Lubuklinggau. 
Rekrutmen merupakan penetapan pola Rekrutmen yang tepat sesuai dengan sifat dan teknis Rekrutmen yang bersangkutan, mekanisme dan prosedur Rekrutmen sesuai dengan stuktur organisasi yang berlaku, penanganan proses Rekrutmen dilakukan oleh petugas yang berwenang, mampu, trampil dan profesional sesuai persyaratan spesifikasi tugasnya dan optimalisasi penggunaan sarana prasarana dalam rangka menunjang teknis Rekrutmen. Oleh sebab itu Rekrutmen yang baik tentunya akan memberikan kepuasan bagi setiap konsumen pada PT. Sindang Brothers Kota lubuklinggau.

\section{PENUTUP}

\section{Kesimpulan}

Berdasarkan hasil penelitian dan pembahasan yang peneliti lakukan, maka dapat disimpulkan bahwa Rekrutmen berpengaruh secara signifikan terhadap Produktivitas Kerja pada PT. Sindang Brothers Kota Lubuklinggau dan Penempatan Kerja juga berpengaruh secara signifikan terhadap Produktivitas Kerja pada PT. Sindang Brothers Kota Lubuklinggau.

\section{Saran}

Hasil penelitian menunjukan bahwa Rekrutmen dan Penempatan Kerja berpengaruh terhadap Produktivitas Kerja pada PT. Sindang Brothers Kota Lubuklinggau, oleh karena itu mengingat pentingnya hal tersebut hendaknya :

1. Pihak PT. Sindang Brothers Kota Lubuklinggau lebih meningkatkan Rekrutmen sehingga dapat meningkatkan kinerja yang semakin baik dan berkualitas.
2. Pihak manajemen PT. Sindang Brothers Kota Lubuklinggau perlu meningkatkan Penempatan Kerja pada variabel-variabel yang menurut penilaian konsumen belum sesuai dengan yang diharapkan oleh konsumen PT. Sindang Brothers Kota Lubuklinggau.

\section{DAFTAR PUSTAKA}

Edy Sutrisno, (2009). Manajemen Sumber Daya Manusia. Jakarta :Kencana

Malayu S.P. Hasibuan, (2009). Manajemen Sumber Daya Manusia (Edisi Revisi). Jakarta: Penerbit Bumi Aksara.

Riduwan dan Sunarto, (2009).Pengantar Statistika (untuk Penelitian Pendidikan, Sosial, Ekonomi Komunikasi, dan Bisnis). Bandung: Alfabeta.

Purwati, Astri, Ayu \& Satria, Hendri. (2018). Pengaruh Perekrutan, Motivasi, Dan Pelatihan Terhadap Kinerja Karyawan Pada CV. Skala Sport Pekanbaru. PROCURATIO (Jurnal Ilmiah Manajemen), 5(4): 418-429.

Sugiyono, (2009).Metode Penelitian Bisnis, Bandung: CV Alfabeta.

Sondang P. Siagian, (2006). Manajemen Sumber Daya Manusia (Edisi Revisi). Jakarta: Bumi Aksara.

Suyadi Prawirosentono, (2008), Kebijakan Produktivitas kerja Karyawan, Yogyakarta: BPFE.

Suharsimi Arikunto, (2005). Prosedur Penelitian suatu Pendekatan PraktekEdisi 5, Jakarta: Rineka Cipta.

Veithzal Rivai, (2004). Manajemen Sumber Daya Perusahaan. Jakarta : Raja Grafindo Persada 